\title{
ORE MINERALOGY AND MINERAL CHEMISTRY OF PYRITE, GALENA, AND SPHALERITE AT SORIPESA PROSPECT AREA, SUMBAWA ISLAND, INDONESIA
}

\author{
Win Kant ${ }^{* 1,2}$, I Wayan Warmada ${ }^{1}$, Arifudin Idrus ${ }^{1}$, Lucas Donny Setijadji ${ }^{1}$, and Koichiro \\ Watanabe $^{3}$ \\ ${ }^{1}$ Department of Geological Engineering, Gadjah Mada University, Yogyakarta, Indonesia \\ ${ }^{2}$ Department of Geology, Banmaw University, Myanmar \\ ${ }^{3}$ Department of Earth Resource Engineering, Kyushu University, Japan
}

\begin{abstract}
The Soripesa prospect area is located at Maria village, Wawo district, Bima region in the East Sumbawa Island, Indonesia. Lithology is dominantly composed of a lithic-crystal tuff of andesitic and dacitic composition and bedded limestone. The polymetallic epithermal quartz veins are hosted by andesitic volcaniclastic rocks. Within these veins, multiphases, colloform-crustiform, bedding to massive textures with pyrite, sphalerite, galena, chalcopyrite, chalcocite, azurite, and malachite are observed. Selected samples were analyzed by using ore microscopy and SEM-EDX. Ore minerals show replacement, ex-solution, colloform, and zonal textures. The paragenesis diagram was made from a careful study of polished sections and thin sections. Textures of ore minerals such as banded, exsolution, replacement, and zone, have been interpreted to correspond to the order of deposition. In pyrite, the average content of Co $(0.45 \mathrm{wt} . \%)$ is higher than $\mathrm{Ni}$ content $(0.14 w t . \%)$ and it means that their origin may be hydrothermal origin. Average content ratio, Co:Ni is 2.81. Galena shows a low Ag content of $0.07 \%$ in average. But they show a high Au content of $1.48 \%$ in average. Sphalerite shows a low Fe content of $1.04 \%$ in average and occasionally chalcopy-
\end{abstract}

${ }^{*}$ Corresponding author: W. KANT, Department of Geological Engineering, Faculty of Engineering, Gadjah Mada University, Jl. Grafika 2 Yogyakarta, 55281, Indonesia. E-mail: winkant1995@gmail.com rite inclusion/disease also occurred. Ga and Ge contents are also high in sphalerite. Co $>\mathrm{Ni}$ in pyrite, low content of $\mathrm{Ag}$ in Galena, low content of Fe and mole \% FeS in sphalerite, high content of $\mathrm{Ga}$ and $\mathrm{Ge}$, and $\log (\mathrm{Ga} / \mathrm{Ge})$ in sphalerite, show that pyrite, galena, and sphalerite from Soripesa prospect area were formed under low temperature condition of hydrothermal fluid.

Keywords: Ore textures, paragenesis, deposition, hydrothermal fluid, low temperature

\section{Introduction}

The Soripesa prospect area is located in Maria village, Wawo district, Bima regency, West Nusa Tenggara Province. The prospect area is previously owned by PT Bima Baruna Raya Mining (BBRM) and PT Sumbawa Timur Mining. These companies have observed Au-Ag deposit and base metal mineralization. At present, PT Bima Putera Minerals (Indomining Group) has a Mining Permit (exploration stage) for those deposits. The prospect area is mainly composed of andesitic and dacitic volcaniclastic host rocks and small amount of Tertiary bedded limestones. There have five main veins in the Soripesa prospect area, trending nearly north-south. Those veins are hosted in andesitic volcaniclastic rocks (lower Miocene in age). The common ore minerals 
of those veins are chalcopyrite, galena, sphalerite, pyrite, chalcocite, covellite, azurite, and malachite, which are forming as polymetallic epithermal quartz veins.

The purpose of this paper is to identify the ore mineral paragenesis and ore forming processes, and mineral chemistry of some sulfide minerals, especially for pyrite, galena, and sphalerite from polymetallic epithermal quartz veins at Soripesa prospect area, East Sumbawa, Indonesia.

\section{Regional Geology}

The Sumbawa Island forms as a part of the Cenozoic calc-alkaline volcanic inner BandaSunda Arc which is still active up to present. Sunda-Banda island arc is a volcanic arc formed by the interaction of plate subduction slab in the form of Indo-Australia with Asian plate (Carlile and Mitchell, 1994). Sunda-Banda arc is the longest in Indonesia, extending from north Sumatra through Java, Bali, Lombok, and Sumbawa, to east Damar. The shape of the island arc is now being modified in the east due to collision with the Australian-New Guinea continental margin, including East Sumbawa (Hamilton, 1974).

The Sumbawa Island is mainly composed by andesitic to basaltic lava and breccia of the Lower Miocene, with intercalations of tuff and limestone, fresh pyroclastic sequences and shoshonite. This sequence is overlain in parts by dacitic tuff and bedded limestone of the Mid Miocene. These units have been intruded by numerous small to medium bodies (several $\mathrm{km}$ 's) in the Middle to Upper Miocene including andesite, dacite, diorite, trachyte and syenite (Figures 1 and 2). Sumbawa Island, regionally, is intersected by NW-SE and NE-SW trending structures. However, the formation of quartz veining, alteration and mineralization at Soripesa Prospect are related to the N-S faulting (Noya et al, 2009).

\section{Sampling and Analytical Methods}

Eighteen selected samples were made thin sections and polished sections to identify the ore minerals and their textures. Ore textures and ore mineral assemblages are analysed under ore microscopy at Earth Resource Engineering Department, Kyushu University. An Energy Dispersive X-Ray Analyser (EDX or EDA) is also used to provide elemental identification and quantitative compositional information. For SEM-EDX analyses, 15 polished sections and 3 thin sections were used to identify the mineral chemistry by using a SHIMADZU SS-550 SEM with a Genesis 2000 energy dispersive spectrometer (EDX) at the Center of Advanced Instrumental Analysis, Kyushu University. Semiquantitative analyses were performed at an accelerating potential of $15 \mathrm{kV}$, with a beam current of about $6.0 \times 10^{-10} \mathrm{~A}$, and a beam diameter of $3 \mu \mathrm{m}$. All the data were corrected with a ZAF matrix-correction program. The lowest detection limit is $100 \mathrm{ppm}$. Ore minerals such as sphalerite, galena, pyrite, chalcopyrite, chalcocite, azurite, malachite, oxide minerals, and some unknown minerals were analyzed by SEM-EDX for elemental identification and compositional information. Based on the elemental compositions, ore minerals can be estimated and identified their ore genesis, and ore forming processes.

\section{Results and Discussions}

\subsection{Ore Minerals Assemblages and Their Textural Characteristics}

Common ore minerals of the polymetallic epithermal quartz veins at Soripesa prospect area are chalcopyrite $\left[\mathrm{CuFeS}_{2}\right]$, galena [PbS], sphalerite [ZnS], azurite, malachite, chalcocite, covellite, pyrite $\left[\mathrm{FeS}_{2}\right]$, hematite, and other ironoxide minerals.

Chalcopyrite. chalcopyrite is one of abundant ore minerals and also occurs within sphalerite as chalcopyrite disease/inclusion (Figure $3 \mathrm{e}$ ). This texture is called as ex-solution texture. Some chalcopyrite replace in pyrite (Figure $3 \mathrm{~g}$ ). The cracking of some chalcopyrite are also replaced by Fe oxide minerals such as colloform goethite and hematite. Silver inclusions are also occurred in chalcopyrite. 

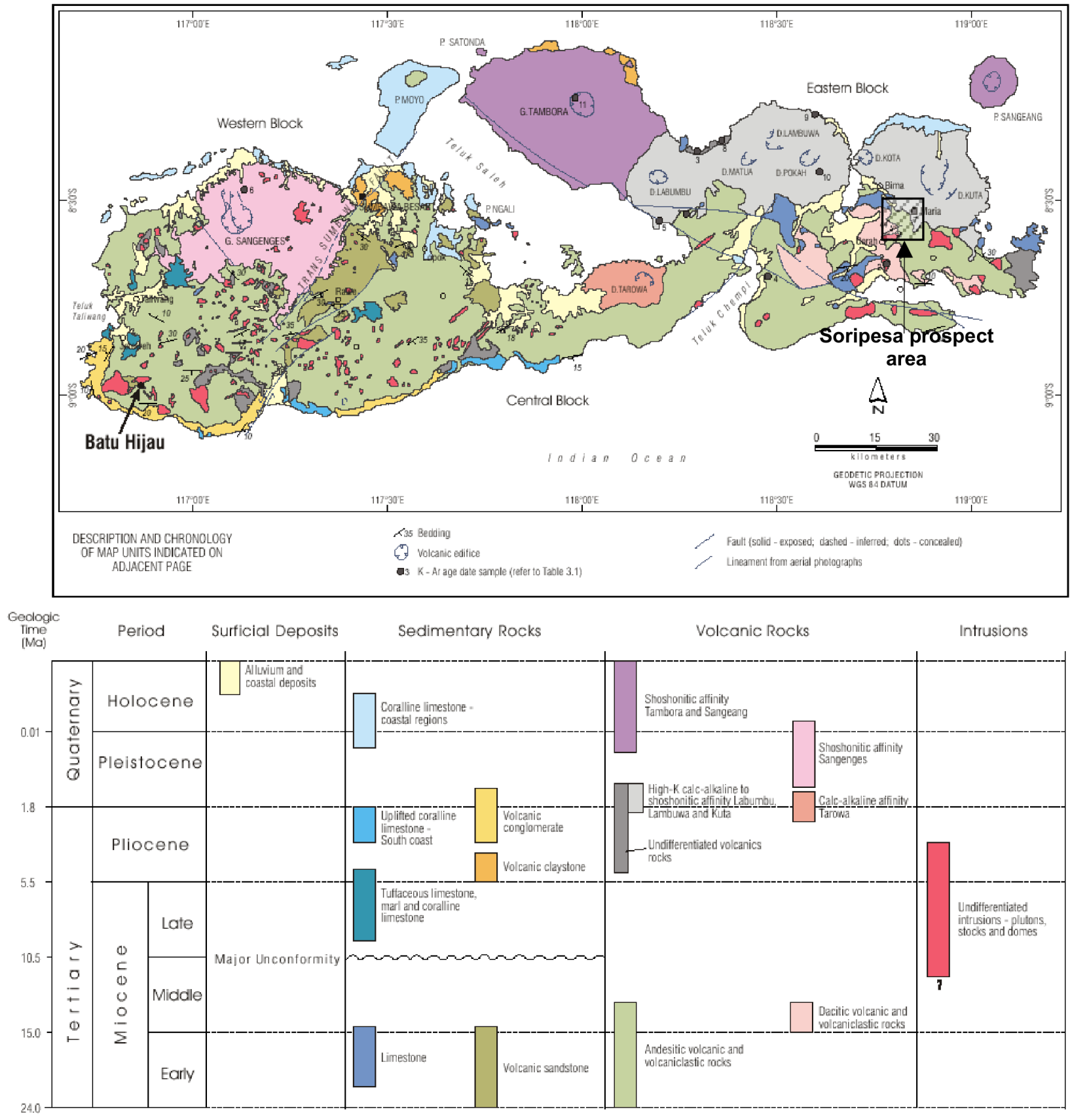

Figure 1: Simplified geologic map and chronology of map units for Sumbawa island, Indonesia including Soripesa prospect area (Source: Garwin, 2002) 


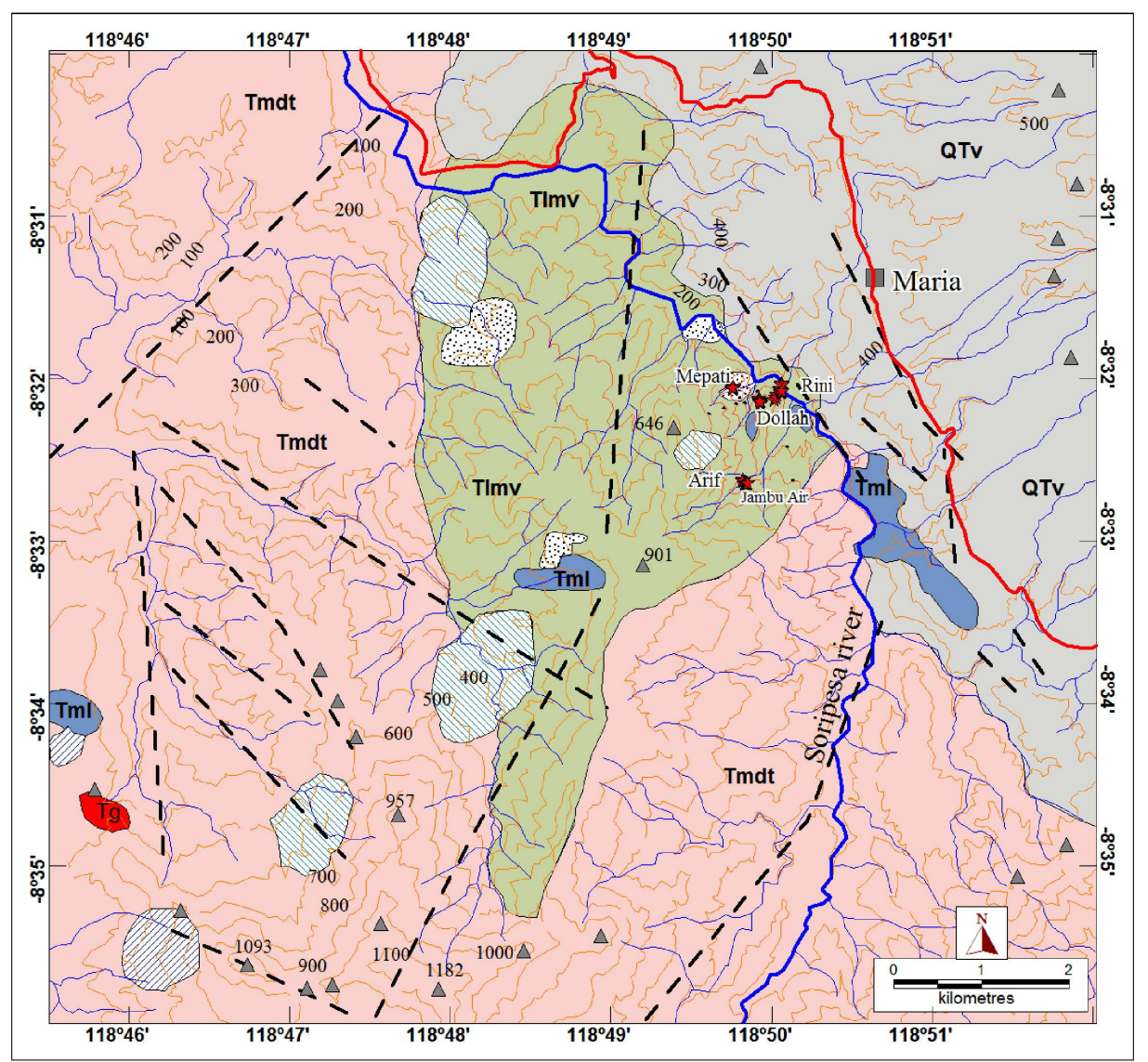

\section{LEGEND}

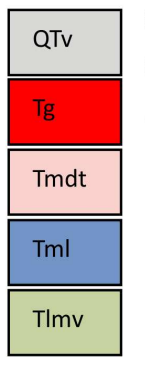

Quaternary agglomerate to breccias andesitic volcanic, not consolidated matrix supported with fragments

Andesite intrusive

Dacitic volcaniclastic, agglomeratic to breccias gradation to fine-grained tuff

Fossiliferous limestone

Andesitic volcaniclastic, agglomeratic to breccias gradation to fine-grained tuff

Highly silicified + pyrite \pm manganese alteration in places silica has been leached out (gossanous) and contains highly oxidized

Clay-quartz alteration

Chlorite-epidote alteration

Quartz vein with base metals mineralization (azurite, chalcopyrite, malachite, galena, sphalerite, pyrite)

Fault $\sim$ River and stream $\sim$ Motor road $\sim$ Contour $(\mathrm{m})$

$\Delta$ Spot high

Figure 2: Geological map of around Soripesa prospect area with epithermal quartz veins (modified after Noya et al, 2009) 
Pyrite. most of pyrite occurs as euhedral form and some are replaced by chalcopyrite. Pyrite occurs in both host rock samples and vein samples. Some are replaced by Fe oxide minerals such as goethite and hematite which are show in concentric texture (Figure 3a). Some pyrite minerals show ribbon texture.

Galena. galena is one of common ore minerals in this research. Some of galena shows a typical texture of triangular pits (Figure 3c). Most of the crystal outlines of galena are generally replaced by chalcocite (Figures $3 \mathrm{c}$ and $3 \mathrm{e}$ ).

Sphalerite. sphalerite is also a common ore mineral of polymetallic epithermal quartz veins in this research area. Most of sphalerite show intergrowth texture with oriented an unoriented inclusions of chalcopyrite (the so-called "chalcopyrite disease"; Barton, 1978). Traditionally, the texture has been described as an exsolution of chalcopyrite from sphalerite. However Barton $(1970,1978)$ and Kalogeropoulos (1982) have convincing evidence that "chalcopyrite disease" is a cancerous replacement produced by $\mathrm{Cu}$ in aqueous solution reacting with $\mathrm{FeS}$ in sphalerite. In some case, the outlines of sphalerite minerals are in general concave toward quartz minerals (Figure 3d). It means that sphalerite is younger than quartz in order of deposition. Sphalerite shows a lot of cracks which are replaced by chalcocite and covellite

Chalcocite. they are found as replacement minerals and replace sphalerite, chalcopyrite, and galena (Figures $3 \mathrm{~b}-\mathrm{e}$ ). In some case, they show colloform textures.

Covellite. they also occur as replacement minerals and replaced mainly in chalcocite. Azurite and malachite are found as hydrothermal alteration minerals. Some azurite shows zonal texture under ore microscopy (Figure 3 e).

\subsection{Ore-gangue Minerals Paragenesis}

The paragenesis for a mineral deposit or a genetically related group of deposits is inferred from the mutual relationships among the minerals and assemblages (Misra, 1999). The interpretation of microscopic textures of ore minerals is very useful to prepare the paragenesis diagrams of those ore minerals. The paragenesis was made from a careful study of polished sections and thin sections. Textures of ore minerals such as banded, exsolution, replacement, and zone, have been interpreted to correspond to the order of deposition. Pyrite and quartz minerals show their euhedral crystal form. It is clear that sphalerite is younger than quartz in order of deposition (Figure 3d). In Figure 3e, it can be seen clear that covellite replace chalcocite, and chalcocite commonly coats and replaces the margins of galena and sphalerite, and sphalerite replace galena. Chalcopyrite inclusions also occur as exsolution textures in crystallographic direction of sphalerite (Figure 3 e). $\mathrm{Fe}$ oxide minerals replace in the cracks of chalcopyrite and pyrite (Figures $3 \mathrm{a}$ and $3 \mathrm{f}$ ). Azurite and malachite occurs as later phase minerals.

Based on the textural characteristics, order of deposition can be divided in to two phases as early phases and later phases. Quartz, galena, pyrite, sphalerite, and chalcopyrite are formed in early stage of deposition. Chalcocite, covellite, azurite, malachite, and Fe oxide minerals are formed later phase of ore deposition. The paragenesis of a mineral deposit can provide a record of the local changes in geochemical parameters ( $\mathrm{T}, \mathrm{P}$, fluid composition, etc.) in the course of mineralization (Bastin, 1955). The paragenesis diagrams of ore and gangue minerals from polymetallic epithermal quartz veins at Soripesa prospect area are shown in Figure 4.

\subsection{Mineral Chemistry of Pyrite, Galena, and Sphalerite}

\section{Minor Elements in Pyrite}

Pyrite is one of the most abundant minerals in the polymetallic epithermal at Soripesa prospect area. 21 pyrite minerals are detected by SEM-EDX to know the elemental composition. Average contents (wt.\%) of some minor elements of pyrite are Cd (0.2), Co (0.45), Ni (0.14), Ag (0.24), Au (1.42), and As (0.75) (Table 1). Some pyrite minerals under SEM-EDX show 

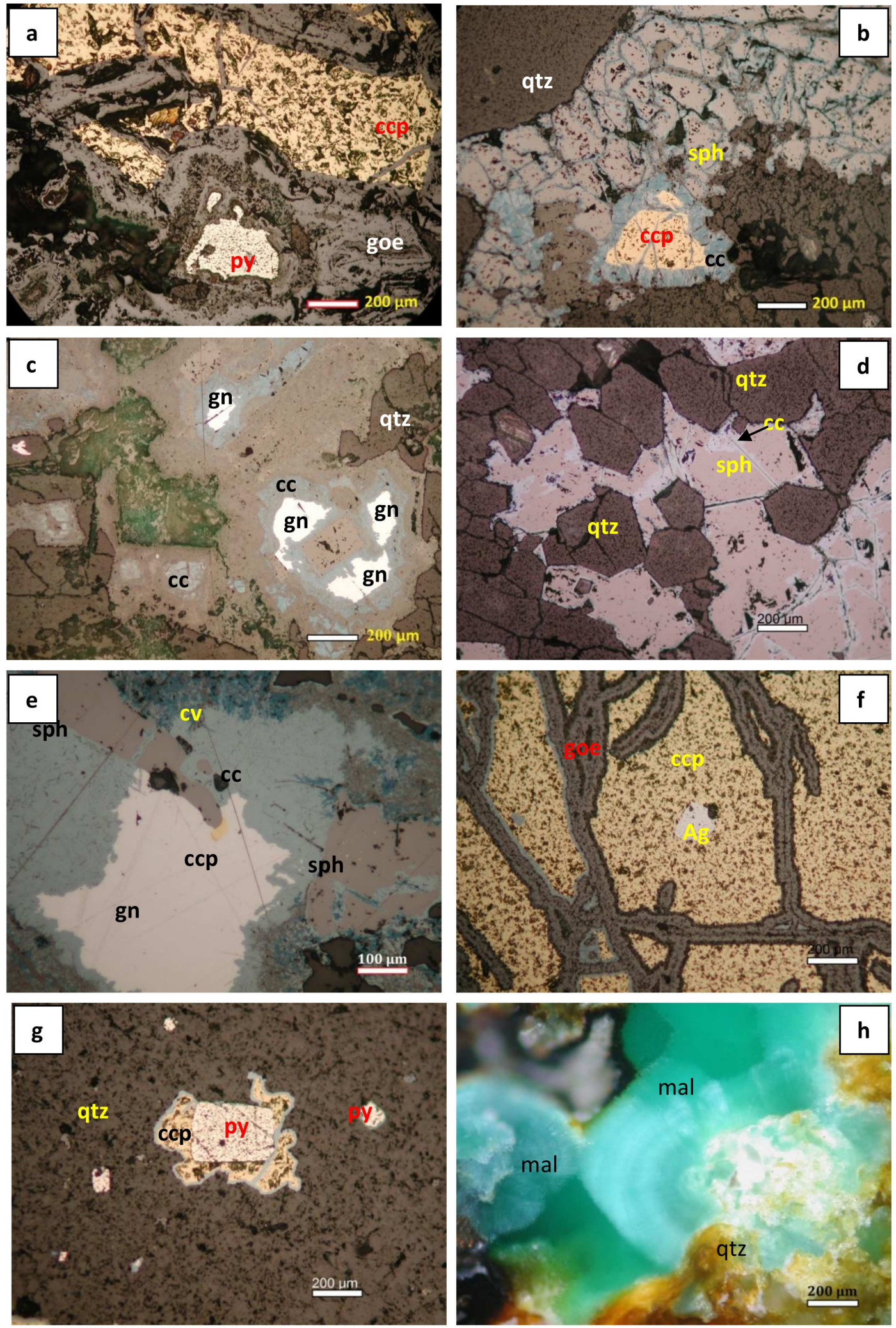

Figure 3: Photomicrographs showing ore mineral assemblages of polymetallic epithermal quartz veins at Soripesa prospect area $(\mathrm{qtz}=$ quartz, $\mathrm{ccp}=$ chalcopyrite, $\mathrm{gn}=$ galena, $\mathrm{Ag}=$ silver, $\mathrm{py}=$ pyrite, $\mathrm{cc}=$ chalcocite, $\mathrm{mal}=$ malachite, and goe $=$ goethite $)$. 


\begin{tabular}{|l|l|l|}
\hline Minerals/Time & Early & Later \\
\hline Quartz (qtz) & & \\
Pyrite (py) & & \\
Galena (gn) & & \\
Sphalerite (sph) & & \\
Chalcopyrite (ccp) & & \\
Chalcocite (cc) & & \\
Covellite (cv) & & \\
Azurite (az) & & \\
Malachite (mal) & & \\
Hematite (hem) & & \\
Goethite (goe) & & \\
\hline
\end{tabular}

Figure 4: Paragenetic diagram of ore-gangue minerals assemblage of polymetallic epithermal quartz veins at Soripesa prospect area.
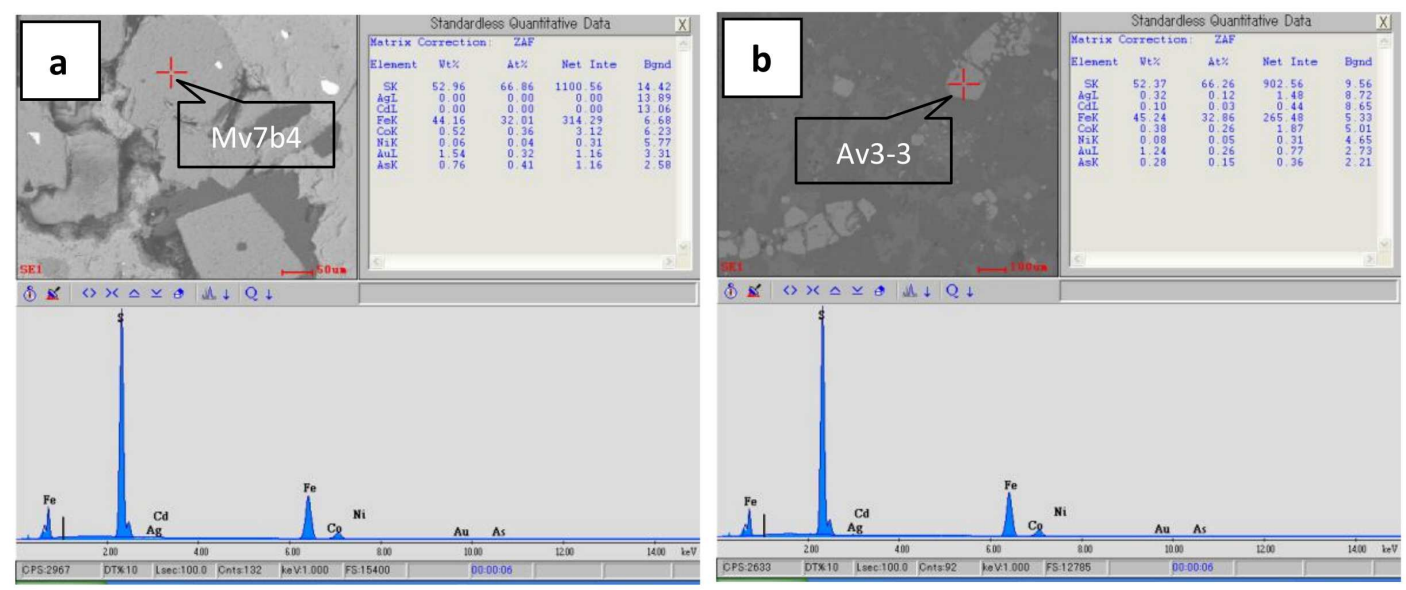

Figure 5: Elemental composition and peak intensity of some pyrite minerals detected by SEM-EDX analyses.

Table 1: SEM-EDX analyses of element composition (wt.\%) of Pyrite minerals. Element composition (normalized wt.\%) of Pyrite minerals.

\begin{tabular}{|rlllllllllr|}
\hline No. & Samples & $\mathrm{Fe}$ & $\mathrm{S}$ & $\mathrm{Cd}$ & $\mathrm{Co}$ & $\mathrm{Ni}$ & $\mathrm{As}$ & $\mathrm{Ag}$ & $\mathrm{Au}$ & $\mathrm{Co} / \mathrm{Ni}$ \\
\hline 1 & Av3-1 & 43.57 & 52.25 & 0.26 & 0.51 & 0.20 & 1.05 & 0.25 & 1.74 & 2.55 \\
2 & Av3-2 & 44.19 & 53.41 & 0.24 & 0.20 & 0.09 & 0.61 & 0.24 & 1.01 & 2.22 \\
3 & Av3-3 & 45.24 & 52.37 & 0.10 & 0.38 & 0.08 & 0.28 & 0.32 & 1.24 & 4.75 \\
4 & Dv10-1 & 43.08 & 52.11 & 0.38 & 0.72 & 0.35 & 1.03 & 0.28 & 2.05 & 2.06 \\
5 & Dv10-2 & 45.92 & 51.17 & 0.28 & 0.53 & 0.14 & 0.95 & 0.13 & 0.87 & 3.79 \\
6 & Dv10-3 & 44.57 & 52.98 & 0.22 & 0.36 & 0.17 & 0.62 & 0.33 & 0.75 & 2.12 \\
7 & Dv10-5 & 44.35 & 52.51 & 0.18 & 0.52 & 0.19 & 0.56 & 0.13 & 1.56 & 2.74 \\
8 & JA5-2 & 44.50 & 52.02 & 0.33 & 0.39 & 0.14 & 0.87 & 0.33 & 1.42 & 2.79 \\
9 & Mv7a1 & 43.71 & 51.18 & 0.31 & 0.65 & 0.25 & 0.90 & 0.49 & 2.51 & 2.60 \\
10 & Mv7a2 & 45.11 & 52.29 & 0.15 & 0.44 & 0.19 & 0.62 & 0.20 & 1.00 & 2.32 \\
11 & Mv7a3 & 44.56 & 52.66 & $<0.01$ & 0.36 & 0.21 & 0.78 & $<0.01$ & 1.42 & 1.71 \\
12 & Mv7a4 & 47.83 & 48.78 & $<0.01$ & 0.29 & 0.13 & 0.86 & $<0.01$ & 2.11 & 2.23 \\
& Avg & 44.60 & 52.19 & 0.20 & 0.45 & 0.14 & 0.75 & 0.24 & 1.42 & 2.81 \\
\hline
\end{tabular}


Table 2: Geometric means of cobalt (Co) and nickel (Ni) contents (in ppm) and $\mathrm{Co:Ni}$ ratios of sediment, hydrothermal, and massive sulphide pyrite minerals (Xuexin, 1984).

\begin{tabular}{|c|c|c|c|}
\hline Type of pyrite & $\mathrm{Co}$ & $\mathrm{Ni}$ & $\mathrm{Co}: \mathrm{Ni}$ \\
\hline This paper & 4500 & 1400 & 2.81 \\
\hline Sedimentary & 41 & 65 & 0.8 \\
\hline $\begin{array}{l}\text { Volcano-hydrothermal, } \\
\text { metamorphosed and } \\
\text { skarn-hydrothermal }\end{array}$ & 141 & 121 & $2-3$ \\
\hline $\begin{array}{l}\text { Volcanogenic Massive } \\
\text { Sulphide }\end{array}$ & 486 & 56 & 3.5 \\
\hline
\end{tabular}

their image, result of element composition (normalized wt.\%) and peaks of elements (Figure 4).

Xuexin (1984) mentioned a statistically significant difference among sedimentary, hydrothermal (replacement veins), and massive sulfide pyrites (Table 2). According to his study, the massive sulfide pyrites are characterized by a Co:Ni ratio between 5 and 50; hydrothermal pyrites by a variable Co:Ni ratio (often less than 5); and sedimentary pyrites by a much lower Co:Ni ratio (typically $<1$ ). Pyrite from sulfide ore deposits generally contains appreciable amounts of cobalt and has $\mathrm{Co}>\mathrm{Ni}$.

According to Carstens (1942), pyrite of sedimentary origin is characterized by containing less than $100 \mathrm{ppm}$ cobalt and $\mathrm{Co}<\mathrm{Ni}$, whereas pyrite of hydrothermal origin has 400-2400 ppm cobalt and Co $>$ Ni. Pyrite from high-temperature deposits is generally high in cobalt, but noted exceptions and considered that the effect of temperature was slight. In this research, average content of Co (0.45 wt.\%) is higher than Ni content $(0.14 \mathrm{wt} . \%)$ and it means that their origin may be hydrothermal origin. Pyrite of high-temperature and hydrothermal sulfide deposits has only a slightly higher average nickel content than pyrite of sedimentary origin and the ranges of concentration overlap. Hawley (1952) found that Ni content was a little higher in high-temperature samples. Average ratio for $\mathrm{Co} / \mathrm{Ni}$ is 2.81 . The $\mathrm{Co} / \mathrm{Ni}$ ratios for volcano-hydrothermal, metamorphosed volcanogenic and skarn-hydrothermal pyrites are in the range of 2-3 (Xuexin, 1984). It means that pyrites from Soripesa prospect area may be formed under the hydrothermal condition.

There is a correlation between As and S, and no correlation between As and Fe in pyrite of this research (Figures 7a-b). These relations indicate substitution of As for $S$ in the pyrite structure, as would be expected for pyrite containing $\mathrm{As}^{1-}$ (Deditius et al, 2009). There is also a correlation between Au and Ag but no correlation between $\mathrm{Au}$ and As (Figures 6a-b).

\section{Minor Elements in Galena}

Galena is also common ore minerals of epithermal quartz veins in this research area. 16 galena minerals were detected by SEM-EDX for their mineral chemistry. Some detected minor elements of galena from this research are $\mathrm{Fe}(1.4$ wt.\%), Hg (1.92 wt.\%), Ag (0.07 wt.\%), Au (1.48 wt.\%), Sb (0.39 wt.\%), and Se (1.05 wt.\%) (Table 3). SEM image, peaks of elements, and results of element composition (normalized wt.\%) of some Galena analysed by SEM-EDX are shown in Figure 8.

Tischendorf (1955) found that the antimony content (present at least in part as tetrahedrite) decreased with decreasing temperature of formation. Schroll (1955) considers the presence of bismuth in galena to be a mark of hightemperature magma-near deposits. Galena in this research has below detection limit of bismuth. Schroll (1955) found that the content of silver varied directly with those of antimony and bismuth and inversely with content of arsenic. Fleischer (1956) reported that the content of silver, bismuth, and antimony are decreased with decreasing temperature of formation. Silver content $(0.07)$ is very low and it means that galena from this research may be formed in decreasing temperature of formation.

\section{Minor Elements in Sphalerite}

Sphalerite is one of the most useful indicators of the environment of ore deposition because of its refractory nature, wide distribution in natural environments, and wide range of composition resulting from substitution of $\mathrm{Zn}$ by Fe (Misra, 1999). Detected minor elements in spha- 

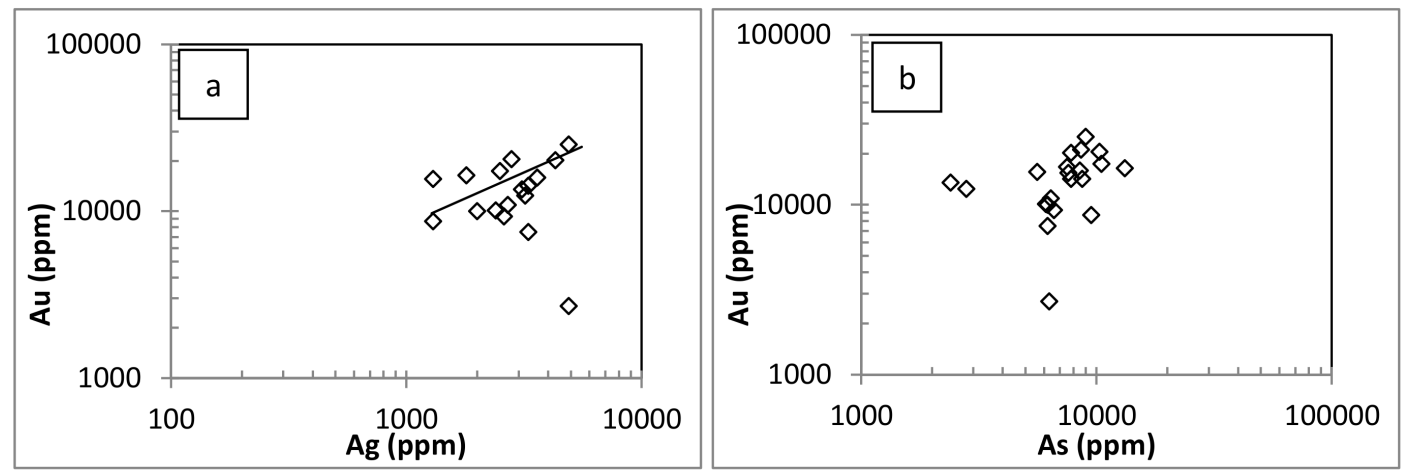

Figure 6: Plots showing correlation diagrams of $\mathrm{Au}, \mathrm{Ag}$, and As concentration in pyrite.
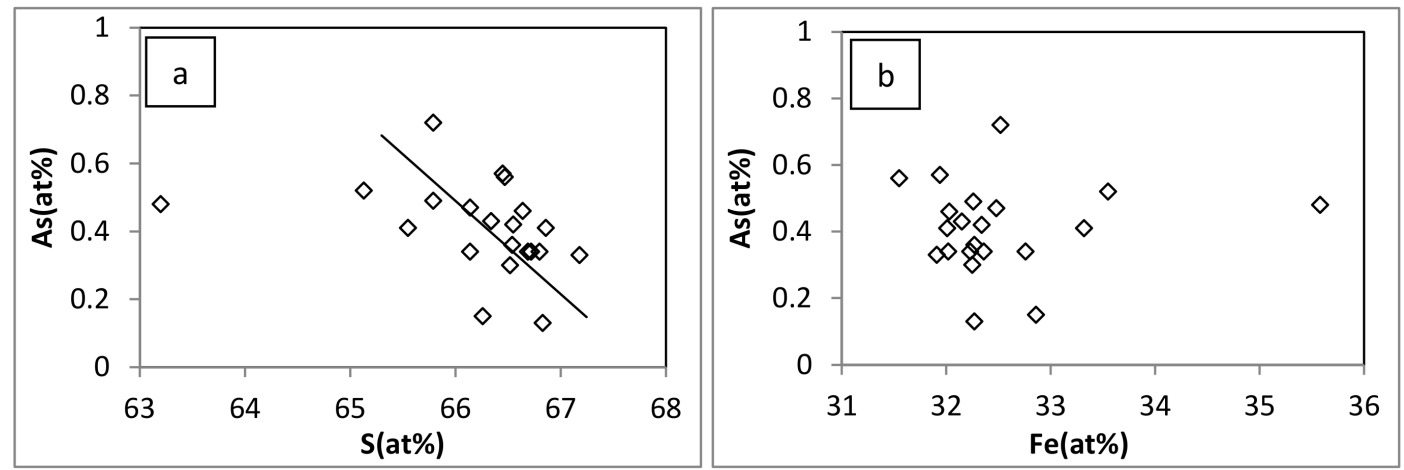

Figure 7: Plots showing correlation diagrams of As, S, and Fe concentration in pyrite.
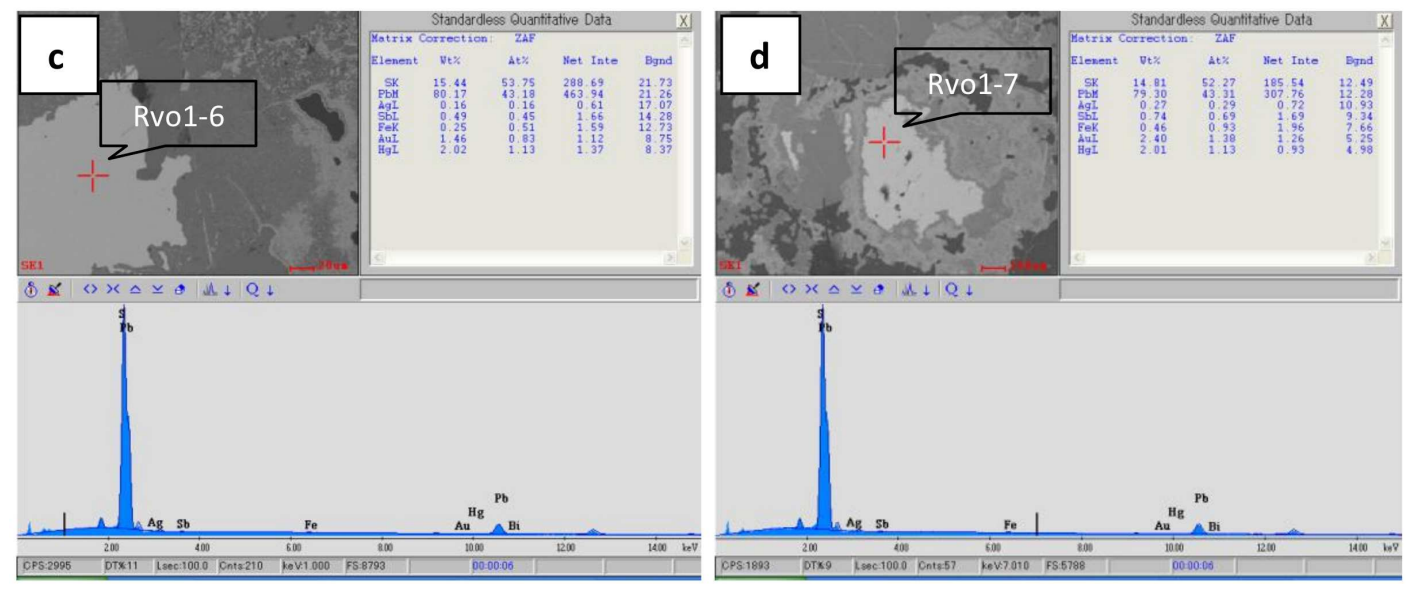

Figure 8: Elemental composition and peak intensity of some galenas detected by SEM-EDX analyses. 
Table 3: SEM-EDX analyses of element composition (wt.\%) of galena. Element composition (normalized wt.\%) of Galena minerals.

\begin{tabular}{|rlllllllll|}
\hline No. & Samples & $\mathrm{Pb}$ & $\mathrm{S}$ & $\mathrm{Fe}$ & $\mathrm{Hg}$ & $\mathrm{Sb}$ & $\mathrm{Ag}$ & $\mathrm{Au}$ & $\mathrm{Se}$ \\
\hline 1 & Av3-4 & 77.70 & 14.16 & 3.97 & 1.24 & 0.42 & $<0.01$ & 1.39 & 0.95 \\
2 & Av3-5 & 76.03 & 14.00 & 3.84 & 2.47 & 0.54 & 0.23 & 1.15 & 1.55 \\
3 & Av3-6 & 77.05 & 14.33 & 3.12 & 2.30 & 0.13 & $<0.01$ & 2.04 & 1.03 \\
4 & Av3-7 & 78.17 & 14.58 & 3.49 & 1.51 & 0.32 & $<0.01$ & 1.27 & 0.66 \\
5 & Av3-8 & 77.86 & 14.68 & 3.82 & 1.11 & 0.51 & $<0.01$ & 0.97 & 0.36 \\
6 & Av3-15 & 77.89 & 14.52 & 0.33 & 2.64 & 0.48 & $<0.01$ & 1.88 & 1.35 \\
7 & Av3-16 & 78.32 & 14.72 & 0.34 & 2.26 & 0.28 & $<0.01$ & 1.46 & 1.72 \\
8 & Av3-17 & 80.31 & 15.52 & 0.33 & 0.91 & 0.18 & $<0.01$ & 0.56 & 0.81 \\
9 & Rvo1-6 & 80.17 & 15.44 & 0.25 & 2.02 & 0.49 & 0.16 & 1.46 & $\mathrm{n} / \mathrm{a}$ \\
10 & Mv4-1 & 79.56 & 15.17 & 0.37 & 2.66 & 0.22 & $<0.01$ & 2.02 & $\mathrm{n} / \mathrm{a}$ \\
11 & Mv4-2 & 79.85 & 14.93 & 0.34 & 2.46 & 0.71 & $<0.01$ & 1.71 & $\mathrm{n} / \mathrm{a}$ \\
12 & Rvo1-7 & 79.30 & 14.81 & 0.46 & 2.01 & 0.74 & 0.27 & 2.40 & $\mathrm{n} / \mathrm{a}$ \\
& Avg & 79.02 & 14.83 & 1.41 & 1.92 & 0.39 & 0.07 & 1.48 & 1.05 \\
\hline
\end{tabular}

$(\mathrm{n} / \mathrm{a}=$ not analysed $)$

lerite are $\mathrm{Fe}(1.04 \mathrm{wt} . \%), \mathrm{Ga}(0.7 \mathrm{wt} . \%), \mathrm{Ge}(0.54$ wt.\%), Cd (0.7 wt.\%), and Ag (0.2 wt.\%). Au content is below detection limit in all sphalerite (Table 4). Figure 9 show the result of some sphalerite minerals analysed by SEM-EDX. The results show SEM image, peaks of elements, and elemental composition in wt.\%.

Jonasson and Sangster (1978) investigated the $\mathrm{Zn} / \mathrm{Cd}$ ratios of sphalerites from some sulphide ores in Canada and concluded that the $\mathrm{Cd}$ contents and $\mathrm{Zn} / \mathrm{Cd}$ ratios in sphalerites vary with the genetic types of deposit. The $\mathrm{Zn} / \mathrm{Cd}$ ratios (average 93.34) in sphalerite from the Soripesa prospect area are close to $\mathrm{Zn} / \mathrm{Cd}$ ratios (104-214) of sphalerites from hydrothermal deposits and skarn-hydrothermal deposits. Stoiber (1940) and Schroll, (1955) considered that the gallium content is most likely to be high in sphalerites from low-temperature deposits such as those of Mississippi Valley type and in those from low-temperature quartz veins.

In this research, average Ga content $(0.7 \%)$ in sphalerites is very high and it means that they may be formed under low temperature condition. Many investigators agree that sphalerite from low-temperature deposits to be higher in germanium content than those from mesothermal or high-temperature deposits (Stoiber, 1940; Warren and Thompson, 1945, Fleischer, 1999). In this research, average content of Ge $(0.54 \%)$ is also very high. Vaughan and Craig (1997) suggested that a zinc concen- trate from a pyritic ore may contain 61-63 wt.\% $\mathrm{Zn}$, but a concentrate from a pyrite-pyrhotite ore will often contain only 51-58 wt.\% zinc and be considerably less valuable. The average content of $\mathrm{Zn}(63.48 \mathrm{wt}$.\%) in sphalerite of this research may be related with pyritic ore condition.

\section{Sphalerite Geothermometry and Geobarometry}

A very interesting recent development is the $\mathrm{Ga} / \mathrm{Ge}$ geothermometer using sphalerite (Moller, 1985). Ga/Ge can be used to determine temperatures in the source regions of ore solutions and to estimate the degree of mixing of hot parental ore fluids with cool, near surface waters (Evans, 1993). Ten samples were simultaneously detected levels for these two elements. The application of these geothermometer results of calculating the logarithm follows:

$$
\log [(\mathrm{Ga} / \mathrm{Ge}) \mathrm{f} \log [(\mathrm{Ga} / \mathrm{Ge}) \mathrm{sph}]
$$

Note that: $\mathrm{f}=$ mineraliser fluid; $\mathrm{sph}=$ sphalerite.

Determining the values of $\log (\mathrm{Ga} / \mathrm{Ge})$ for the analyzes of sphalerite minerals, we obtain the values in the ranges between -0.4 to 1.15. These values are applied to the chart geothermometer $\mathrm{Ga} / \mathrm{Ge}$, based on geothermometer of $\mathrm{Al} / \mathrm{Si}$, and in this case that of muscovitechlorite-quartz, given the degree of metamor- 

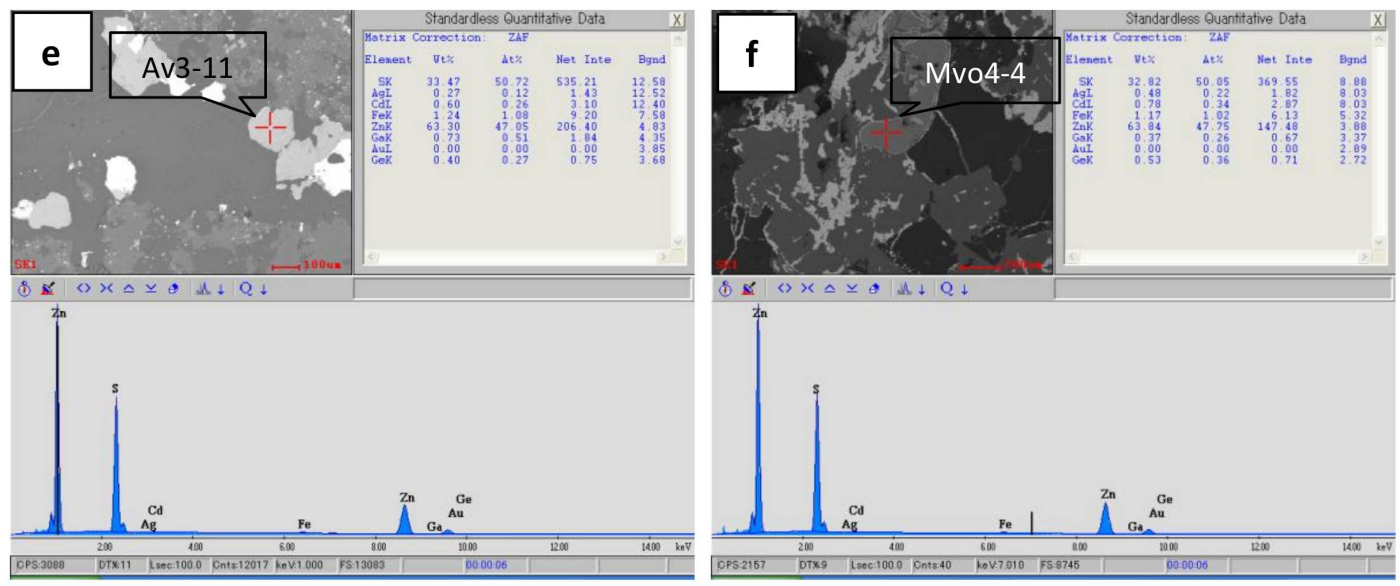

Figure 9: Elemental composition and peak intensity of some sphalerites detected by SEM-EDX analyses.

Table 4: Chemical SEM-EDX analyses of element composition (wt.\%) of sphalerites.

\begin{tabular}{|c|c|c|c|c|c|c|c|c|c|c|}
\hline No. & Samples & $\mathrm{Zn}$ & $\mathrm{S}$ & $\mathrm{Fe}$ & $\mathrm{Ga}$ & $\mathrm{Ge}$ & $\mathrm{Cd}$ & $\mathrm{Ag}$ & $\mathrm{Au}$ & $\mathrm{Zn} / \mathrm{Cd}$ \\
\hline 1 & Av3-9 & 62.82 & 34.14 & 1.08 & 0.68 & 0.29 & 0.65 & 0.34 & $<0.01$ & 96.65 \\
\hline 2 & Av3-10 & 63.22 & 33.81 & 1.21 & 0.71 & 0.54 & 0.50 & $<0.01$ & $<0.01$ & 126.44 \\
\hline 3 & Av3-11 & 63.30 & 33.47 & 1.24 & 0.73 & 0.40 & 0.60 & 0.27 & $<0.01$ & 105.50 \\
\hline 4 & Av3-12 & 62.29 & 35.27 & 0.56 & 0.65 & 0.36 & 0.63 & 0.25 & $<0.01$ & 98.87 \\
\hline 5 & Rvo1-1 & 64.31 & 32.62 & 1.11 & 0.50 & 0.48 & 0.64 & 0.34 & $<0.01$ & 100.48 \\
\hline 6 & Rvo1-2 & 63.81 & 33.21 & 0.93 & 0.83 & 0.25 & 0.71 & 0.26 & $<0.01$ & 89.87 \\
\hline 7 & Rvo1-3 & 63.38 & 33.38 & 0.84 & 0.59 & 0.71 & 0.83 & 0.27 & $<0.01$ & 76.36 \\
\hline 8 & Rvo1-4 & 64.07 & 32.00 & 1.10 & 0.92 & 0.65 & 0.86 & 0.40 & $<0.01$ & 74.50 \\
\hline 9 & Rvo1-5 & 63.79 & 32.24 & 1.17 & 1.06 & 0.84 & 0.77 & 0.12 & $<0.01$ & 82.84 \\
\hline \multirow[t]{2}{*}{10} & Mvo4-4 & 63.84 & 32.84 & 1.17 & 0.37 & 0.92 & 0.78 & 0.48 & $<0.01$ & 81.85 \\
\hline & Avg & 63.48 & 33.30 & 1.04 & 0.70 & 0.54 & 0.70 & 0.27 & $<0.01$ & 93.34 \\
\hline
\end{tabular}


phism. The chart shows the values of temperatures between 180 to $240^{\circ} \mathrm{C}$. Figure 10 presents the projection of the respective analysis chart that correlates the race $\mathrm{Ga} / \mathrm{Ge}$ with the temperature. This graph is based on geothermometers known systems of $\mathrm{Al} / \mathrm{Si}$ and published data for reasons of $\mathrm{Ga} / \mathrm{Ge}$ in many geological systems (Möller, 1985; 1987).

Neiva (1956) considers that the presence of Ge is higher in sphalerites that are formed at low temperature. Based on the fluid inclusion data from quartz (host minerals), ranges of homogenization temperature for quartz veins is between 180 and $300^{\circ} \mathrm{C}$ (Khant et al, 2012a). The temperature differences observed between the two geothermometers can be related to the mixing and circulation of fluids late and/or prefluid surface (Möller, 1985; 1987).

Kullerud (1953) suggested that the FeS content of sphalerite gave a direct measurement of its temperature of deposition. Average Fe content $(1.04 \%)$ of sphalerite in this research is very low. Mole \% FeS in sphalerite is also very low and between 1-2 \%. In $\mathrm{Zn}-\mathrm{Fe}-\mathrm{S}$ of low pressure system, this value (1-2\%) falls in pyrite field (Figure 11). Within the pyrite field the decrease in FeS content of sphalerite with increasing $\mathrm{a}_{\mathrm{S}_{2}}$ (sulfur activity) is much greater resulting in a close spacing of isopleths near the pyrite-pyrrhotite buffer and in very low $\mathrm{FeS}$ contents in sphalerite at high, $\mathrm{a}_{\mathrm{S}_{2}}\left(10^{-10}\right.$ to $10^{-11}$ ). It is commonly found that sphalerites formed at high $\mathrm{a}_{\mathrm{S}_{2}}$ have a honey yellow to light brown colour with their low FeS contents whereas sphalerites formed at low $\mathrm{a}_{\mathrm{S}_{2}}$ and within the pyrrhotite field are dark brown to black (Scott, 1983). Those factors mean they may be formed in low temperature condition.

\section{Conclusion}

Common ore minerals of the polymetallic epithermal quartz veins at Soripesa prospect area are chalcopyrite $\left(\mathrm{CuFeS}_{2}\right)$, galena $(\mathrm{PbS})$, sphalerite ( $\mathrm{ZnS})$, azurite, malachite, chalcocite, covalite, pyrite $\left(\mathrm{FeS}_{2}\right)$, hematite, and other Fe oxide minerals. Common textures of ore minerals are replacemnent, exsolution, banded (colloformcrustifom), and zone textures. The paragene- sis diagram was drawn from a study of polished sections and thin sections under microscope. Ore mineral textures have been interpreted to identify the order of deposition and to made paragenesis diagram. Quartz, pyrite, galena, sphalerite and chalcopyrite are formed in early stage and chalcocite, covelite, azurite, malachite, and Fe oxide minerals are formed in late stage of order of deposition.

Pyrite, galena, and sphalerite are analysed by SEM-EDX to know the elemental compositions. Average contents (wt.\%) of some minor elements of pyrite are Cd (0.2), Co (0.45), $\mathrm{Ni}$ (0.14), Ag (0.24), Au (1.42), and As (0.75). Some detected minor elements of galena from this research are $\mathrm{Fe}(1.4 \mathrm{wt} . \%), \mathrm{Hg}$ (1.92 wt.\%), Ag (0.07 wt.\%), Au (1.48 wt.\%), Sb (0.39 wt.\%), and Se (1.05 wt.\%). Detected minor elements in sphalerite are Fe (1.04 wt.\%), Ga (0.7 wt.\%), Ge (0.54 wt.\%), Cd (0.7 wt.\%), and Ag (0.2 wt.\%). Average content of Co (0.45) is higher than $\mathrm{Ni}$ content (0.14) and average ratio for $\mathrm{Co} / \mathrm{Ni}$ is 2.81 in pyrite from this research. It means that origin of pyrite from this research may be hydrothermal origin. Based on the low contents of $\mathrm{Sb}, \mathrm{Bi}$, and $\mathrm{Ag}$ in average, we can conclude that galena from this research are formed in decreasing temperature of formation.

The $\mathrm{Zn} / \mathrm{Cd}$ ratios (average 93.34) in sphalerite from the Soripesa prospect area are close to $\mathrm{Zn} / \mathrm{Cd}$ ratios (104-214) of sphalerites from hydrothermal deposits. Low content of Fe, and high content of $\mathrm{Ga}$ and $\mathrm{Ge}$, also indicate that sphalerites from this research are formed in low temperature quartz veins. Based on $\mathrm{Ga} / \mathrm{Ge}$ geothermometer, the formation temperatures of sphalerites can be estimated and they may be formed at between 180 and $240^{\circ} \mathrm{C} .1$ to 2 Mole \% $\mathrm{FeS}$ in sphalerite indicate that ore deposition formed under high $\mathrm{a}_{\mathrm{S}_{2}}\left(10^{-10}\right.$ to $\left.10^{-11}\right)$ and associated with pyrite field.

\section{Acknowledgement}

The authors want to express deep thanks to AUN/SEED-Net and JICA program for their financial supporting to do this research. And then, thankful acknowledgements are due to Indo mining group for their kind helps and per- 


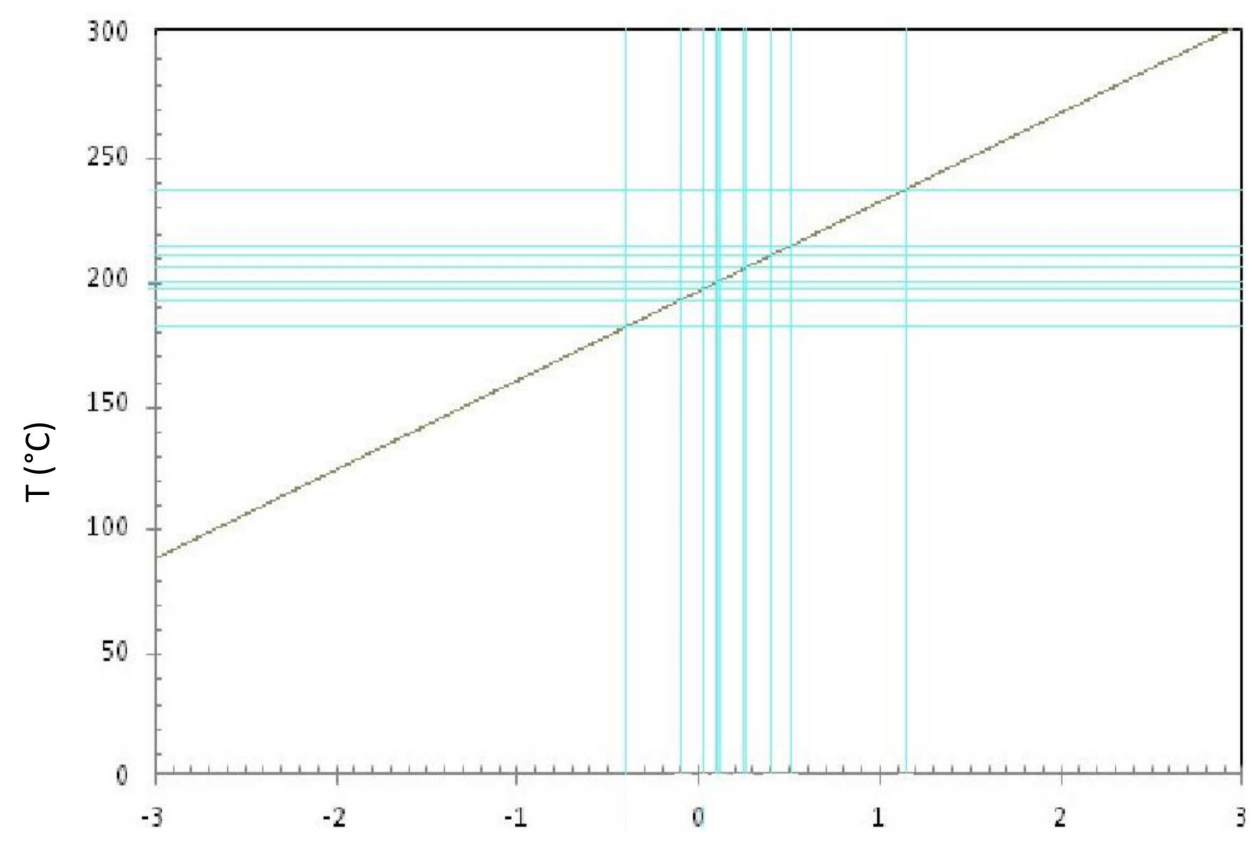

$\log (\mathrm{Ga} / \mathrm{Ge})$ Sphalerites

Figure 10: Graph showing the dependence between $\mathrm{Ga} / \mathrm{Ge}$ ratios in sphalerite and formation temperature. This graph is based on existing $\mathrm{Al} / \mathrm{Si}$ geothermometers. The musc-clo-qtz line is the chlorite geothermometer in the Si / Al system (Möller, 1985; 1987).

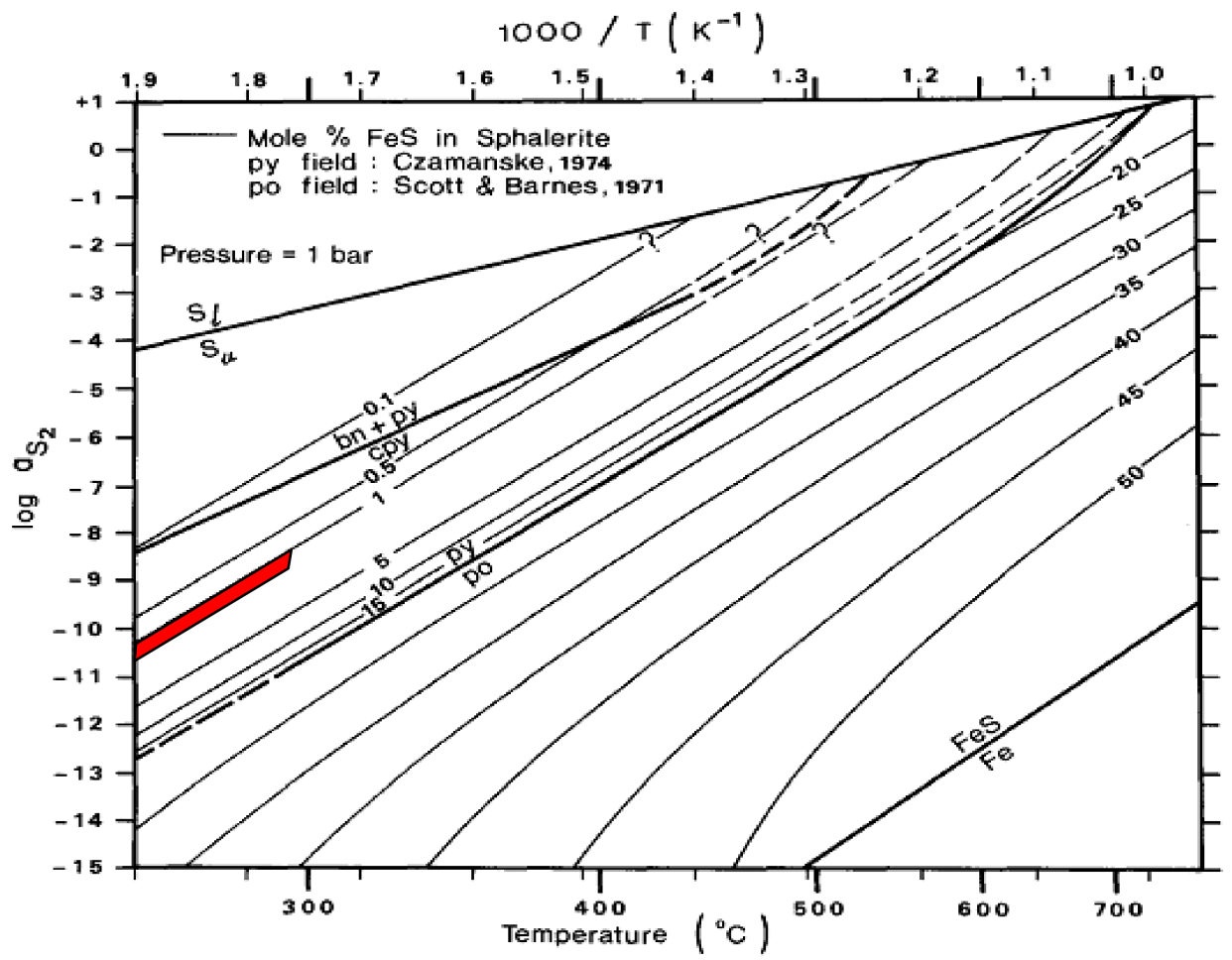

Figure 11: Phase relationships for the Fe-Zn-S system at 1 bar compiled from Barton and Toulmin (1966), Scott and Barnes (1971) and Czamanske (1974). Red line represents the sulfur activity of sphalerite in this research. Abbreviations: $\mathrm{bn}=$ bornite; $\mathrm{cpy}=$ chalcopyrite po = pyrhotite; $\mathrm{py}=$ pyrite; $S 1$ = liquid sulphur; $S v=$ sulphur vapour. 
mission during the field work. Finally, the authors wish to thank Earth Resources Engineering Department, Kyushu University for performing laboratory works and analyses.

\section{References}

Barton, P.B., Jr. (1978) Some ore textures involving sphalerite from the Furutobe Mine, Akita Prefecture, Japan, Mining Geology 28: 293-300.

Barton, P.B., Jr. (1970) Mineral Society of America, Special Paper 3: 187-198.

Barton, P.B., Jr. and Toulmin, P. III. (1966) Economic Geology 61: 815-849.

Bastin, E.S. (1955) Interpretations of ore textures, The Geological Society of America, Memoir 45, $101 \mathrm{p}$.

Carlile, J.C. and Mitchell, A.H.G. (1994) Magmatic arcs and associated gold and copper mineralization in Indonesia, Journal of Geochemical Exploration 50: 91-145.

Carstens, C.W. (1942) Uber den Co-Ni-Gehalt norwegischer Schwefelkies-vorkommen: Kgl. Norske Videnskabs, Selgkabs, Forh. 15: 165-168.

Deditius, A.P., Utsunomiya, S., Kesler, S.E., Ewing, R.C., and Walshe, J. (2009) Behaviour of trace elements in arsenian pyrite in ore deposits, The 10th Biannual Meeting of SGA, Townsville, 17-20 August. Smart Science for Exploration and Mining 1-2, p. 710-712.

Evans, A.M. (1993) Ore Geology and Industrial Minerals: An Introduction, Blackwell scientific publications, 3rd Ed., 390p.

Fleischer, M. (1956) Minor Elements in Some Sulfide Minerals? Economic Geology, 50th Anniversary Volume, p. 970-1024.

Garwin, S. (2002) The Geologic Setting of IntrusionRelated Hydrothermal Systems near the Batu Hijau Porphyry Copper-Gold Deposit, Sumbawa, Indonesia. Global Exploration 2002: Integrated Methods for Discovery, Colorado, USA, 9, p. 333366.

Hamilton, W. (1974) Tectonics of the Indonesian region. U.S. Geol. Surv., Prof. Pap. 1078p.

Hawley, J.E. (1952) Spectrographic studies of pyrite in some Eastern Canadian mines, Economic Geology 47: 260-304.

Jonasson, I.R. and Sangster, D.F. (1978) Zn:Cd ratios for sphalerites separated from some Canadian sulphide ore samples, Paper Geol. Surv. Canada 78-1B: 195-201.
Kalogeropoulos, S.I. (1982) Chemical sediments in the hanging wall of volcanogenic massive sulfide deposits. Ph.D. thesis, Univ. Toronto, 488 p.

Khant, W., Warmada, I W., Idrus, A., Satijadji, L.D., and Watanabe, K. (2012) Fluid Inclusion Study on Polymetallic Epithermal Quartz Veins at Soripesa Prospect Area, Sumbawa Island, Indonesia. Journal of Southeast Asian Applied Geology (in preparation).

Kullerud, G. (1953) The FeS-ZnS system: a geological thermometer. Nor. Geol. Tiddskr. 32: 61-147.

Misra, K.C. (1999) Understanding Mineral Deposits, Kluwer Academic Publisher, 758p.

Möller, P. (1985) Development and application of the $\mathrm{Ga} / \mathrm{Ge}-\mathrm{Geothermometer} \mathrm{for} \mathrm{sphalerite} \mathrm{from} \mathrm{sed-}$ iment hosted deposits, In Germann K. (ed.), Geochemical aspects for Ore Formation in Recent and Fossil Sedimentary Environments, p. 15-30.

Möller, P. (1987) Correlation of Homogenization Temperatures of Acessory Minerals from Sphalerite-bearing Deposits and Ga/Ge Model Temperatures, Chemical Geology 61: 153-159.

Noya, Y., Effendhy, O., Hamdan Abidin, Z., and Pakaya, Y. (2009) Geological background and economic prospect of the Soripesa deposit, eastern Sumbawa, Proceeding pit IAGI Semarang, 2009. The 38th IAGI annual Convention and Exhibition Semarang, 13-14, October.

Scott, S.D. (1983) Chemical behavior of sphalerite and arsenopyrite in hydrothermal and metamorphic environments. Mineralogical Magazine 47: 427-435.

Schroll, E. (1955) Uber das Vorkommen einiger Spurenmetalle in Blei-Zink-Erzen der ostalpinen Metallprovinz, Tshermaks Mineralog, Petrog, Mitt. 5: 183-208.

Stoiber, R.E. (1940) Minor elements in Sphalerite, Economic Geology 35: 501-519.

Tischendorf, G. (1955) Paragenetische und tektonische Untersuchungen auf Gangen des fluorbarytischen bleiformation Freibergs, Freiberger Forschungshefte, C18: 1-129.

Vaughan, D.J. and Craig, J.R. (1997) Sulfide Ore Mineral Stabilities, Morphologies, and Intergrowth Texture, In Barnes H.L. (ed.) Geochemistry of Hydrothermal Ore Deposits, John Wiley \& Sons, p. 367-434.

Warren, H.V. and Thompson, R.M. (1945) Sphalerites from western Canada. Economic Geology 40: 309-335.

Xuexin, S. (1984) Minor Elements and Ore Genesis of the Fankou Lead-Zinc Deposit, China. Mineral Deposita 19: 95-104. 